\title{
A Comparative Study of Municipal Solid Waste Management Status for Three Major Towns of Upper Assam-India
}

Moharana Choudhury ${ }^{1}$ and Joystu Dutta ${ }^{2 *}$

${ }^{1}$ Department of Environmental Science, Tezpur University Assam, India

${ }^{2}$ Department of Environmental Science, Sarguja University, Chhattisgarh, India

\begin{abstract}
Waste is a major problem for the countries and cities of developing country like India. This present study is carried out to understand the present scenario of waste management status of three major towns of Assam state namely Jorhat, Tezpur and Dibrugarh. A comparative analysis is carried out on the basis of municipal solid waste generation in these three prominent municipalities of Upper Assam. During the present study it is estimated that Tezpur town produces around $28 \mathrm{MT}$ of waste, Jorhat Town produces $35 \mathrm{MT}$ of waste and Dibrugarh Town produces 75 MT of waste respectively. All the three Municipalities are facing problem for disposal of waste as the open dumping ground is affecting the people and environment around the site. Dibrugarh town waste management is more critical compare to others as because of the open air dumping system since 25 years as well as proximity to river Brahmaputra dike area which is unsuitable and unscientific for dumping process. The intermixing of waste with riparian ecosystem leads to further complications and far-reaching consequences. There is a good scope of Biogas production and vermicompost generation from waste dumping areas because in average almost $90 \%$ waste is bio-degradable. There is immediate need of advanced technical measures to handle the waste management in these towns further.
\end{abstract}

Keywords: Municipal solid waste management; Riparian ecosystem; Vermicompost; Biogas

\section{Abbreviation}

MSW: Municipal Solid Waste; MT: Metric Ton; HHW: Household Hazardous Waste; TMB: Tezpur Municipal Board; JMB: Jorhat Municipal Board; DMB: Dibrugarh Municipal Board

\section{Introduction}

It is estimated that population of India would increase from 1029 million to 1400 million during the year $2001-2028$, by $42 \%$ at the rate of $5.2 \%$ annually. There are near about 852 million people live in rural areas and 325 million live in urban areas. The estimated rate of urbanization of India has increased from $26.5 \%$ to $38 \%$ in the last $50-60$ years and which is expected to rise unto $44 \%$ by the year 2026. It is an interesting fact that, in India there is sharp increase in the numbers of metro cities from 23 to 35 in the last few years. The population in Class I cities (metropolitan cities), urban centres and metro cities is having a population of more than 1 million [1]. This conglomeration of urban centres is generating Municipal Solid Waste estimated to 1.3 billion tonnes every year, and expected to increase up to 2.2 billion tonnes by 2025 [2]. Annually, Asia alone generates 4.4 billion tonnes of solid wastes and MSW comprise 790 million tonnes (MT) of which about 48(6\%) MT are generated in India [2,3]. By the year 2047, MSW generation in India, is expected to reach $300 \mathrm{MT}$ and land requirement for disposal of this waste would be $169.6 \mathrm{~km}^{2}$ [3]. This represents a significant increase in per capita waste generation rates from $1.2 \mathrm{~kg}$ to $1.42 \mathrm{~kg}$ per person per day in the next fifteen years [3]. However, global averages are broad estimates only as rates vary considerably by region, country, city, and even within cities. Rapid urbanization with accelerated industrial growth is a key factor of urban waste generation. Urban waste is a major environmental issue which directly relates with human health concern [4]. In most of the developing countries, municipal solid waste disposal has been a chronic problem, particularly in areas with high population density, high production of refuse, and scarcity of land adequate for landfills with scientific measures [5]. Our environment is facing a potential threat from unsustainable waste disposal system which is a burning issue in almost all urban cities and peri urban pockets. Some wastes are secondary resource products; these are recovered products or form recycling as recovered materials [6].

Generation of solid waste is not a new phenomenon. Municipal waste is the refuse that arises out of human activities which includes household refuses, commercial waste, street sweeping, construction debris etc. The term 'Solid Waste' includes garbage (food waste), rubbish (paper, plastic, wood, metal, rag etc.) demolition products (bricks, masonry and pipes), sewage treatment residues, dead animals manure and other waste materials. The prediction of municipal solid waste generation plays an important role in a solid waste management [7].

It has been estimated that India generates about 62 million tonnes of trash every year with solid waste being on average of $0.4 \mathrm{~kg}$ capita per day [8] (Table 1). The composition and the quantity of MSW generated forms the basis on which the management system needs to be planned, designed and operated. In India, MSW differs greatly with regard to the composition and hazardous nature, when compared to MSW in the western countries [9-11].

The current study is an attempt in this direction to identify, inventorize and assess the municipal waste generation system in three emerging towns of Assam and develops a roadmap through a critical comparative analysis of best waste generation system in practice. The study also attempts to analyze the gaps and measures to fill it up through effective strategies over time.

*Corresponding author: Dutta J, Department of Environmental Science, Sarguja University, Darripara, Ambikapur, Chhattisgarh 497001, India, Tel: +91 7049804500; E-mail: joystu.dutta@gmail.com

Received August 01, 2017; Accepted August 07, 2017; Published August 14 2017

Citation: Choudhury M, Dutta J (2017) A Comparative Study of Municipal Solid Waste Management Status for Three Major Towns of Upper Assam-India. Int Waste Resour 7: 291. doi: 10.4172/2252-5211.1000291

Copyright: (c) 2017 Choudhury M, et al. This is an open-access article distributed under the terms of the Creative Commons Attribution License, which permits unrestricted use, distribution, and reproduction in any medium, provided the original author and source are credited. 


\section{Methodology}

The assessment of the current situation of urban solid waste management system of a particular city is very important in terms of environmental concern [12]. It proved by many research, that the most environmental problem resulting from poor waste management systems which because of greenhouse gas emissions, water pollution, soil pollution and resources depletion etc. thus waste management is very important for sustainable development [13]. Collection of secondary data's from the municipality boards, Government departments as town and country planning office, revenue office, agriculture department, field visit observation, social survey of towns, interviews with officials and staffs of waste management unit of respective municipal boards, citizens of towns etc. Secondary data collected from Municipal boards to assess the present urban solid waste management scenario of the towns of upper Assam, some photographs also taken from the different part of towns at the time of survey along with dumping ground and surrounding areas.

\section{Study areas}

Tezpur, Jorhat and Dibrugarh town of Upper Assam, India. Tezpur town is situated $26.65^{\circ} \mathrm{N}, 92.79^{\circ} \mathrm{E}$ on the northern bank of river Brahmaputra and is administrative headquarters of Sonitpur district. It is one of the fast growing cities with a population above one lakh. The town is around 175 kilometres away from Guwahati, the state capital. Tezpur is considered as 'Cultural Capital of Assam' and has also earned the Clean City status.

The geographic location of Jorhat town is $26.75^{\circ} \mathrm{N} 94.22^{\circ} \mathrm{E}$. The area is having average elevation of 116 metres from sea level. The largest riverine inhabiting island of the world i.e., Majuli was in Jorhat district before but now it is recently declared separate district hood out of Jorhat in October 2016 [14]. Majuli island area is now around 924.6 square kilometers with inhabiting population of about 150,000 . This wonderful island is threatened by constant riverine erosion. It is a pilgrimage place since Ahom rulers. Several Satras (monasteries) are there in Majuli.

Dibrugarh town is located at $27.47^{\circ} \mathrm{N}, 94.91^{\circ} \mathrm{E}$. It is the headquarters of the Dibrugarh district in the state of Assam. Dibrugarh is known as 'tea centre of India' and is well connected with Guwahati. It is a big industrial hub of Assam. Dibrugarh is located $439 \mathrm{~km}$ (273 miles) from Guwahati.

Tezpur town is the administrative headquarters of Sonitpur district of Assam towns with a population around 80,575 as per 2011 census report. The average temperature in summer is around $25^{\circ} \mathrm{C}\left(77^{\circ} \mathrm{F}\right)$ while the average winter temperature is around $13^{\circ} \mathrm{C}\left(55^{\circ} \mathrm{F}\right)$. Tezpur towns having different communities as Assamese, Bengali, Nepali, Bihari, Marwari communities, tea-tribes, Bodos, Mishings etc. Tezpur town is having some major intuitions and educational hub of Assam. Tezpur Municipal Board was founded in the year 1894. The Geographical expansion of the area included within Tezpur municipal board extends

from $26.37 \mathrm{kms}$ in length and $92.4930 \mathrm{kms}$ in breadth and lies at an altitude of $236 \mathrm{ft}$ from sea level. There are at present 19 wards in Tezpur municipality as with the flow of time the total area of land under Tezpur Municipal Board raised to 7.10 Square Kilometres. There are 10 numbers of slums in Tezpur municipality area as: 1) Jahajghat 2) Hill View 3) Arikati 4) Kasari Gaon Hulla 5) Harizan Colony 6) Rubber Bagan 7) Nepali Patty 8) Kolibari 9) Ganesh Ghat 10) Garuwan Patty (Figure 1).

Jorhat town is head quarter of Jorhat District of Assam, India. Jorhat town is situated by N.H-37 and about $300 \mathrm{~km}$ away from Guwahati, the capital city of Assam. It is directly link with other part of the country by an airport and railways. Jorhat town is situated at the Southern bank of Brahmaputra River and is 72 meter above the mean sea level. The world's oldest and largest Tea research institute is located at Jorhat. The Jorhat municipal board constituted in the year 1909 with a view to rendering civic amenities to the town living people. The Jorhatian are proud of its past glory of its last capital of greatest Ahom kingdom who always dreams and expose to be rather different from other people of the country. The original town area widened to $9.20 \mathrm{sq}$. $\mathrm{km}$ municipality is having 19 wards with population of about 98000 as per 2011 census report Government of India (Figure 2).

\section{A brief description about Dibrugarh town and Dibrugarh municipality}

Dibrugarh town is situated at geographic location $27^{\prime} 28^{\prime} \mathrm{N}$ latitude and $94^{\prime} 35^{\prime} \mathrm{E}$ longitude is the headquarters of the district. Dibrugarh is also one of the two main cities in the state of Assam to receive urban development aid from the Asian Development Bank and is the nerve centre of industry, communication and healthcare of the upper Assam region. Dibrugarh town is $439 \mathrm{~km}$ ( 273 miles) away from state capital i.e., Guwahati. Dibrugarh is well connected by rail, road and air transport services. It is also known as industry town of state of Assam. Dibrugarh town is having population of 1.26 lakhas per 2011 census. Presently having municipal area of is $15.46 \mathrm{~km}^{2}$ and consists of 22 wards (Figure 3 and Table 2).

\section{Results}

\section{Types of waste generation by municipalities}

Mainly there are 4 (four) types of waste are generated mainly such as:

1) Household of domestic waste

2) Market waste

3) Street waste

4) Commercial establishment waste. Other wastes are also there but they are not acute in nature in comparison.

\section{Household or domestic waste}

Household waste consists of ash, garbage and rubbish. Ash is the

\begin{tabular}{|c|c|c|c|}
\hline Year Intervals & Population (Millions) & Per Head \\
\hline 2001 & 197.3 & 0.439 \\
\hline 2011 & 260.1 & 0.498 \\
\hline 2021 & 342.8 & 0.569 \\
\hline 2031 & 451.8 & 0.649 & 31.63 \\
\hline 2036 & 518.6 & 0.693 & 107.01 \\
\hline 2041 & 595.4 & 0.741 & 131.24 \\
\hline
\end{tabular}

Table 1: Year wise comparative study of waste generation in tons/year. 


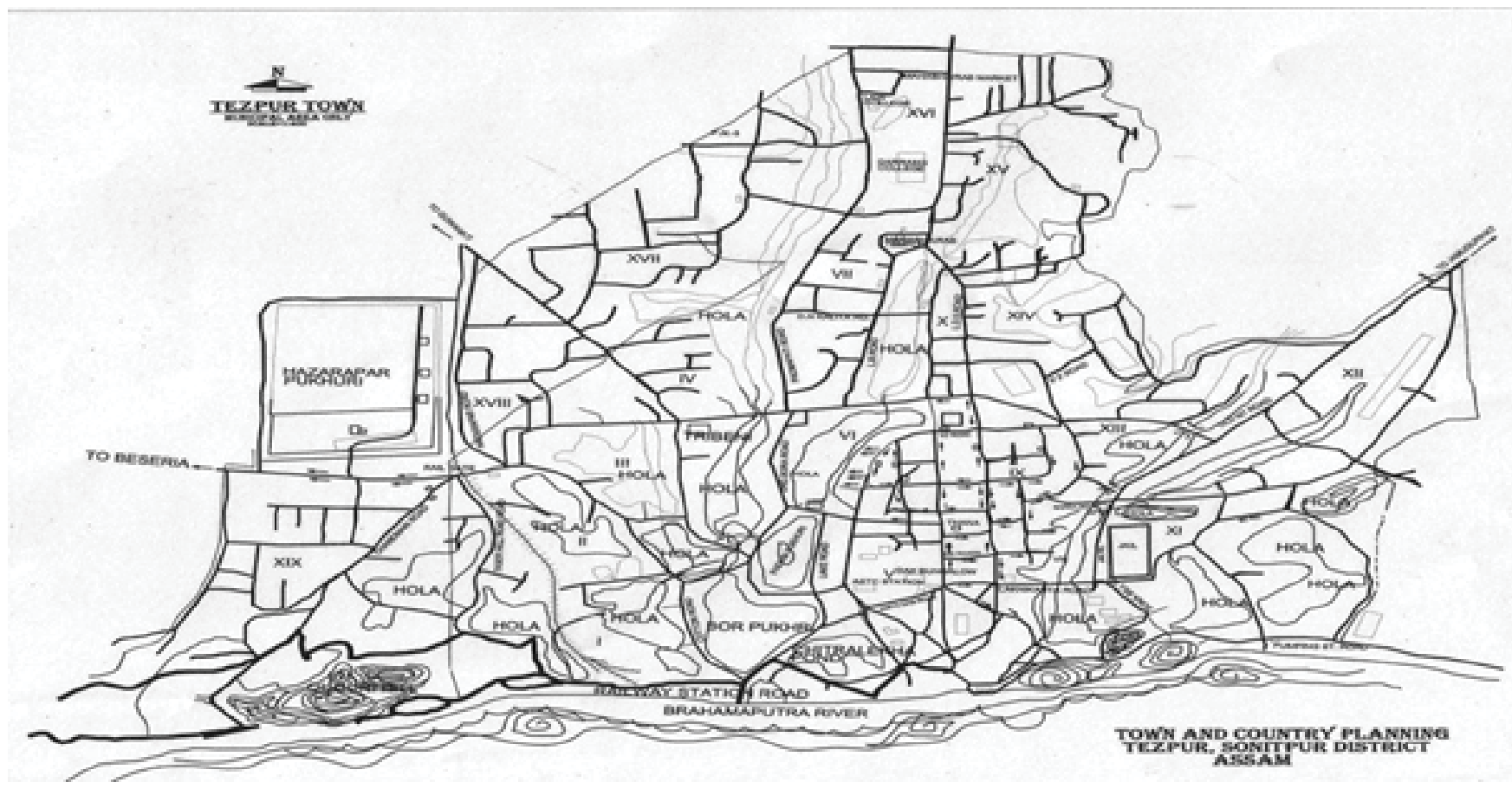

Figure 1: Ward map of Tezpur municipality area. Source: town and country planning Tezpur.

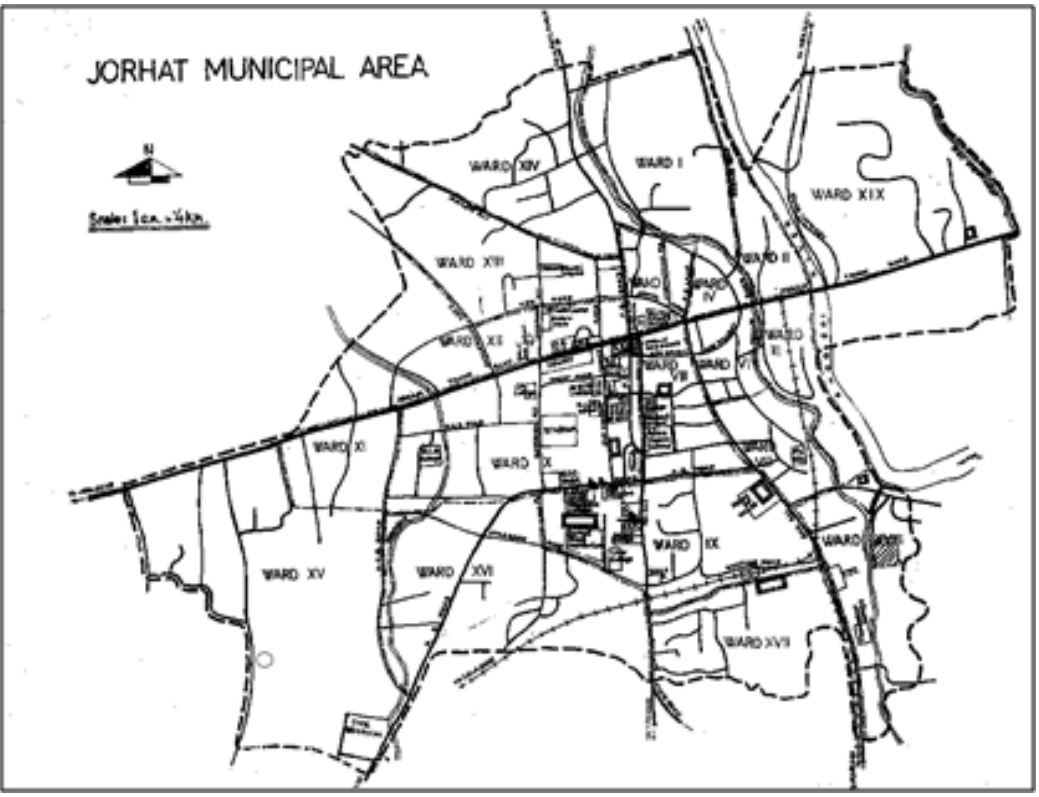

Figure 2: Ward map of Jorhat municipality area. Source: Jorhat municipality board.

residue from fire used for working and heating. Rubbish that consists of papers, clothing, and bits of wood, metal, glass, dust and dirt.

\section{Market waste}

Market Waste is the refuse that is collected from market. It contains large proportion of putrid vegetables, animal matter, and plastic and thermocol etc.

\section{Street waste}

Refuse that is collected by street cleaning services or scavenging process are consists of leaves, straw, paper, animal droppings and litter of all kinds and large quantities of nuisance like plastics, polythene etc.

\section{Other commercial establishment waste}

Refuse arises from commercial establishment like Hotel, Restaurant, 


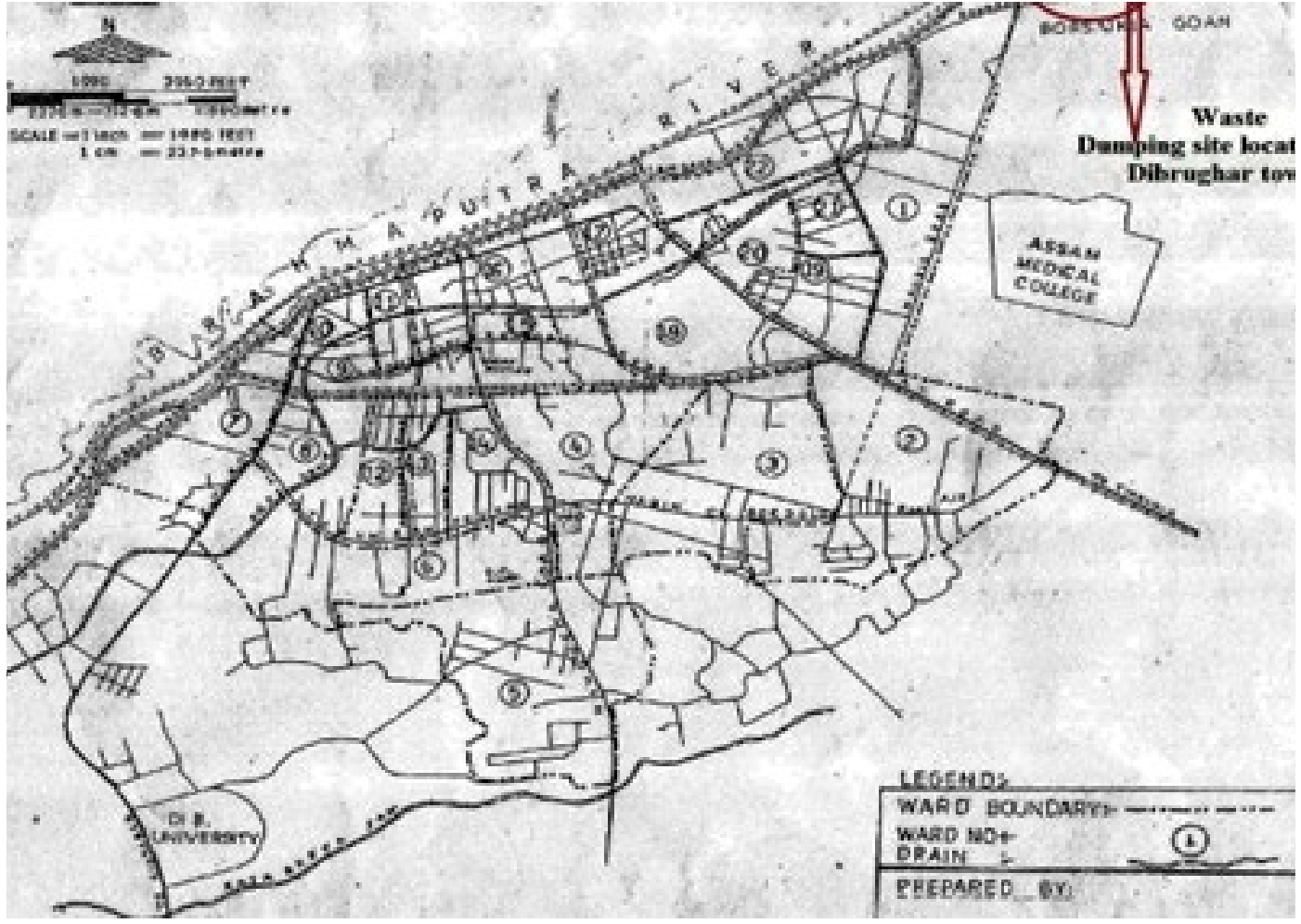

Figure 3: Map of Dibrugarh municipality. Source: Town and country planning Dibrugarh.

\begin{tabular}{|c|c|c|c|c|}
\hline Town & Waste Generation(Estimated) & Population & Nos. of Wards & Area Square Kilometres \\
\hline Tezpur Town & $28 \mathrm{MT}$ & 80,575 & 19 & 7.10 \\
\hline Jorhat Town & $35 \mathrm{MT}$ & 98000 & 19 & 9.20 \\
\hline Dibrughar Town & $75 \mathrm{MT}$ & 1.2600 & 22 & 15.46 \\
\hline
\end{tabular}

Note: Population source: census report, Government of India (2011)

Table 2: Comparative details of three Municipalities Tezpur, Jorhat and Dibrugarh.

and Grocery Shop etc. of non-market area. Refuses from eateries and other waste from grocery etc. are examples of other commercial establishment wastes of all the towns. Other waste like stable litter and household hazardous waste are also generated in small volume (Table 3). Household Hazardous Waste (HHW) deserves special attention as it may be a great concern in future. It includes common household items such as paints, cleaners, oils, batteries and pesticides.

Products labelled as danger, warning, caution, toxic, corrosive, flammable or poison are identified as products that might contain hazardous materials. Left over portion of these products is called household hazardous. If it is placed into the refuse, they may injure the sanitation workers collecting waste. If poured on to the ground or into waterways, they may contaminate water supply. There are 7 drivers are engaged for the waste management service out of them 2 are permanent and others are Master Roll or fixed pay/Daily basis.

Vehicle and equipments: Try-cycles rickshaw (30 nos.), MS container (30 nos.), Three wheeler auto (4 nos.), Bio medical van (1 nos.), Wheel barrow (62 nos.), Dozer attachment (1 nos.), Loader attachment (1 nos.), tractor (2 nos.), tractor trolley (1 nos.), water tanker (1 nos.), tractor trolley (1 nos.), water tanker (1 nos.), tractor (2 nos.), weigh bridge (1 nos.), dumper placer (5 nos.).
Waste dumping site details: Tezpur Municipal Board having a dumping site which is far from the municipal area known as Balichapori, Mouza Mohabhairab having Dag No. 90, 92, 93 which is meant for the construction of Solid Waste Management Project of Tezpur town, the project started on February 4, 2010. There is one recycling unit for organic waste and used these recycled products as manure. The site is found with boundary wall in all side though the area is having settlement but the unit having one in charge personal and some other workers for look after the situation and coming vehicles with waste from town. The urban local body has used RCC bins and metallic containers to store the wastes and 132 numbers of workers were engaged to handle the waste management task. The sweeping crew collects the wastes from road sides and deposit in the nearby community bins by using tricycles. Door to door waste collection system has not yet been started in the Tezpur municipal area. To transfer the wastes two numbers of tractor trailers, a mini truck and a dumper placer were used. Every day, the tractor trailers performed 3 trips each while the mini truck and the dumper placer only 2 trip each. The collected wastes were carried in open trailers and trucks for about 4 Kilometres to the disposal site at Marabharali. The collection drive starts at 7 A.M and continued till 2 P.M in the afternoon under the supervision of four officials of the engineering divisions of the Urban Local Authority maintaining a predesigned schedule. Collected wastes were finally disposed by simply dumping and land-filling processes. 


\begin{tabular}{|c|c|c|}
\hline SL No & Type of Vehicle & Numbers of Vehicle \\
\hline 1 & Container & 5 Nos. \\
\hline 2 & Truck & 1 Nos. \\
\hline 3 & Tractor & 3 Nos. \\
\hline 4 & Sky Jet & 1 Nos. \\
\hline 5 & Swargarath(TATA DI) & 1 Nos. \\
\hline 6 & Cess Pool Truck & 1 Nos. \\
\hline 7 & Tractor JCB & 1 Nos. \\
\hline 9 & Tractor Loader & 1 Nos. \\
\hline 10 & Auto Van & 1 Nos. \\
\hline Total & Total number of transport & 5 Nos. \\
\hline
\end{tabular}

Note: Source: Tezpur municipal board (Waste Management Unit)

Table 3: Infrastructure and human resources availability of municipalities.

\section{Jorhat municipal board (waste management unit)}

Jorhat Municipality use to collect the Garbage from Collection point/ Dustbin since morning $6 \mathrm{AM}$ and dispose the same at Garamur Dumping Ground, $3 \mathrm{~km}$ away from the city. The present system of disposal is open land filling. A research work has been undertaken with Regional Research Laboratory, to find out a suitable technology for disposing the garbage scientifically with minimum expenditure. Until now no treatment plant could be set up for financial constraint of the board. It is estimated that, to establish solid waste plant, a sum of Rs. 2.90 crores would be required to implement the Hon'ble Supreme Court's order on the P.I.L. filed by the Almita H Patel Consequent upon non enforcement of the Bajaj Committee recommendation, that attempted to stem the cause of plague that etched dark chapter in the history of Surat in Gujrat. Town has average waste generation/ day is around $35 \mathrm{MT}$.

\section{Vehicle and equipment's details}

Truck ( 2 nos.), tractor and trailor (4 nos.), hand cart (4 nos.), dust bins ( 65 nos.), persons involved (Table 4 ). Location of dumping ground is inside of municipal area which is surrounded by heavy settlement and the place is known as Gomukh Sasan. There is around 6-7 Khatas of land for open waste dumping which directly affecting surrounding area as one market is there in adjacent of dump yard along with Sasan Ghat of Jorhat Town, the yard is not having any boundary and directly closer to Sasan and inhabiting area. As during the field visit local resident told they need to face problem for the burring of waste and odour that come out from waste there also a problem of rodent and carnivorous birds that attracted by waste and make the area unhealthy. However, manpower support is lacking.

\section{Dibrugarh municipal board (waste management unit)}

Vehicle and equipments details: There are total (250 nos.) of worker including casual and permanent in Dibrugarh municipal Board. Out of these very less persons are for waste management unit compare to that huge waste generation by the town (Figure 4).

There are 3 nos. of experts:

Six nos. of supervisor/moharas involved in waste collection process of DBM. Only (three numbers) of excavators and one dumper for collection process.

Office at Chawkidingi, Dibrugarh (1 nos. sanitary inspector) Mr. Bipul Phukhan (Figure 5).

Dibrugarh Municipal Board dumps the waste of the entire town in an open dumping area known as Maizan, located at Barsikiya Gaon a village, which is situated in $27^{\circ} 30^{\prime} 1.50^{\prime \prime} \mathrm{N}$ and $94^{\circ} 55^{\prime} 59.41^{\prime \prime} \mathrm{E}$ shown in Google Earth satellite imagery of 25th May 2013 in Figure 6 below.

\section{Bramhaputra river}

The open dumping ground is located near the river. This location is totally unscientific as the dumped wastes directly mix with river water through water runoff process. This leads to pollution of river water from both point and non-point sources. Continued inaction affects not only the river water ecosystem but also the water quality of the river. Many communities living along the length of the river are totally dependent on the Brahmaputra for drinking purpose and all other requirements, including source of irrigation, domestic usage, and animal husbandry. Rivers therefore continue to remain the lifeline for people living upstream and downstream of areas which have become dumping grounds.

Unplanned, unscientific dumping of solid waste results in contamination of ground water systems besides affecting surface water sources. The survey and field visit to the dumping area of DMB revealed the following.

- It has been noticed and observed that, dumping site condition is very poor and the site is full of many rodents, birds, flies, animals like pig, cow, dog etc.

- The area is very unhealthy and unhygienic, waste quantity in dumping yard is increasing day by day as per local residents of nearby the site.

- Solid wastes composed of rags, stones, soils, besides food and vegetable waste from kitchen and market etc. even dead animal too.

- Heaps of refuse present at site is causing an unsightly appearance and nuisances from bad odours effecting surrounding area photo shown in Figure 7.

There is plenty of correlation between improper disposal of solid waste and vector borne diseases. Local residents say that DMB resorts to burning of the waste, which also causes air pollution in the surrounding area, with the uncontrolled smoke spreading around, accompanied by a very unpleasant odour. Some residents have complained of breathing problems and irritation in the eyes. So it can be concluded that, present municipal dumping site of Dibrugarh Municipal board is unscientific and unsuitable for waste dumping which is dangerous both for human health and river ecosystem as site is just attached with river shown in Figure 7. There is need for immediate action on the following:

1. Cessation of unregulated dumping

2. Identifying a proper place for disposal of municipal waste 
Citation: Choudhury M, Dutta J (2017) A Comparative Study of Municipal Solid Waste Management Status for Three Major Towns of Upper AssamIndia. Int J Waste Resour 7: 291. doi: 10.4172/2252-5211.1000291

\begin{tabular}{|c|c|}
\hline Category & Nos. \\
\hline Regular & 23 Nos. \\
\hline Master Rule & 53 Nos \\
\hline Supervisor & 1 Nos. \\
\hline In-charge(Asst Engineer) & 1 Nos. (R.Lahan) \\
\hline
\end{tabular}

Table 4: Manpower in Jorhat municipalty.

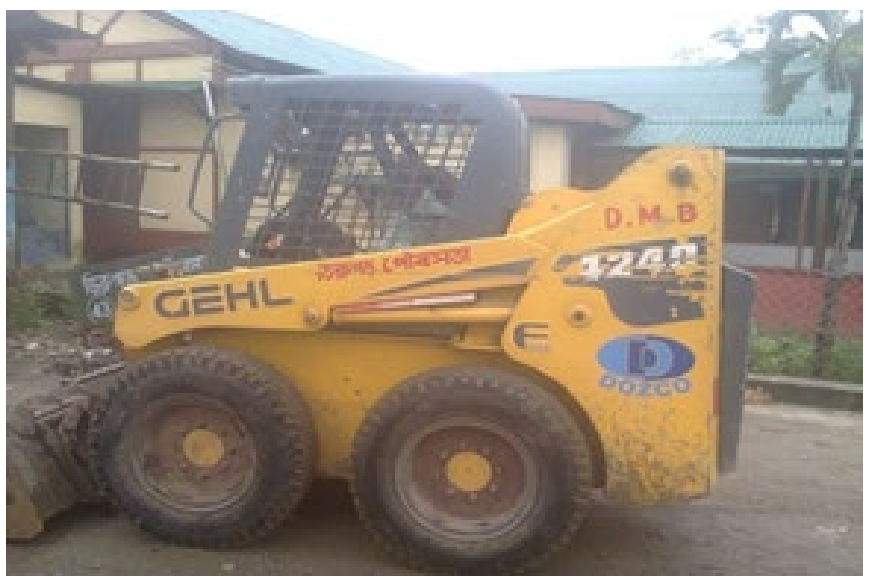

Figure 4: Excavator vehicle used in waste collection in Dibrugarh municipality.

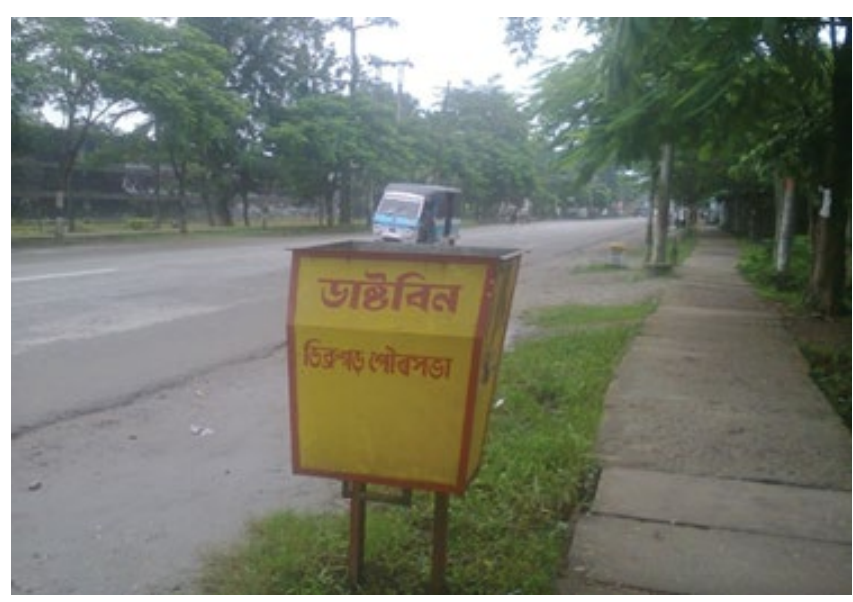

Figure 5: Dustbin of DBM that placed in different part of town area.

3. Public awareness on waste management

4. Waste segregation

Rural India is unfortunately adopting unsustainable urban practices such as use of unmanageable amounts of plastics in packaging of food and non-food items. Lack of awareness about recycling and lack of infrastructure for proper waste disposal has converted wastelands into waste dump yards. Scientific MSW management measures are the need of the hour for a better, healthy and safe environment in Dibrugarh town as well as other parts of lower Assam where livelihoods are entirely dependent on the waters of River Brahmputra.

\section{Infrastructure available with municipal bodies}

Infrastructure is inadequate. From the records of municipality, it is observed that the infrastructure available with the municipal bodied for waste management is extremely inadequate.

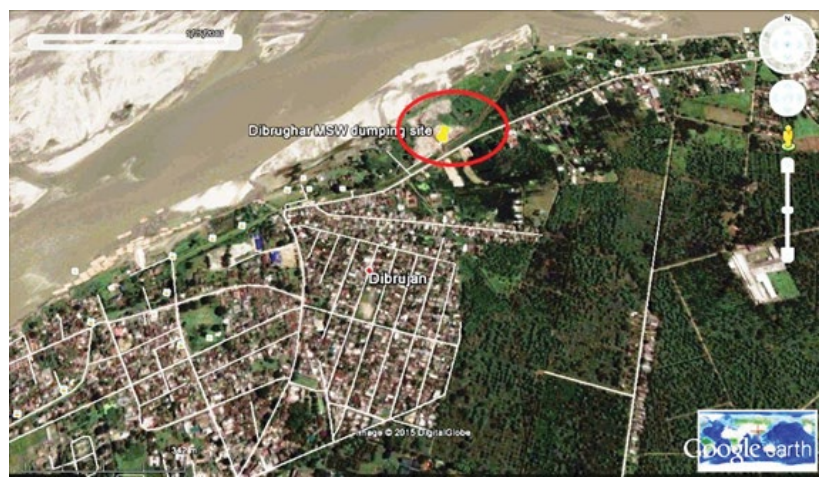

Figure 6: Google satellite imagery of date $25^{\text {th }}$ May 2013 is showing the study area location. The site is just outside from the municipal area but very much near to the embank.

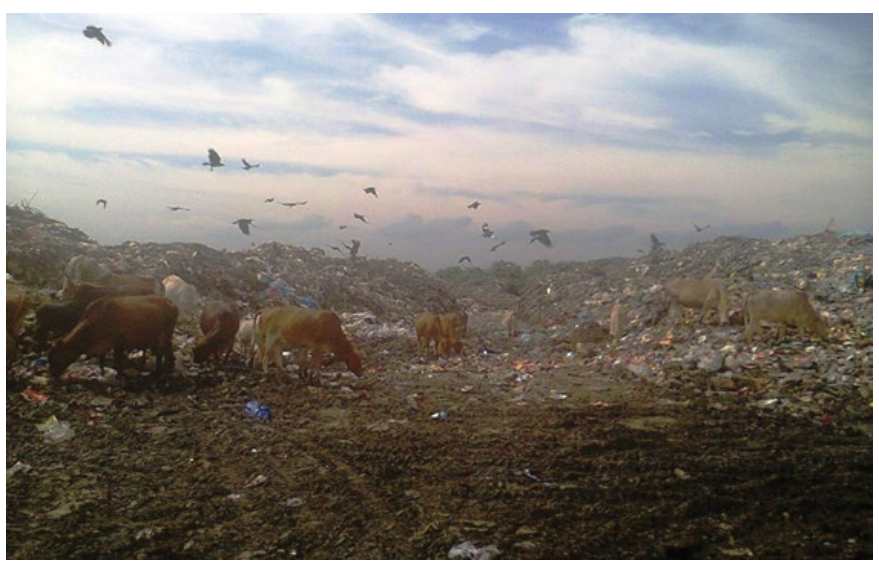

Figure 7: Photo describing the situation of dumping site.

- Vehicles for transportation of waste are not even up to the minimum requirement for daily cleaning of main roads only.

- Human resources, available are also less than minimum requirements.

- There is no fund allocation for waste management except salary of the available staff and expenditure on vehicles.

\section{Waste segregation}

There is no practice of segregation of waste as biodegradable and non-biodegradable except few households of all the towns as the segregation carries no meaning as there is no separate dumping spot or waste collection system (Figure 8 ).

\section{Waste transportation}

Transportation of waste done through uncovered trucks and tractors - trailers of Municipality, Frequency of transportation from specific point of the main roads not more than twice in a week. The loading and unloading of waste are done manually/mechanically by Tractor JCB.

\section{Waste disposal}

Dumping of wastes of all the municipalities is uncontrolled, unscientific and non- segregated bio- degradable and non-biodegradable solid waste dumping is a serious concern. Human habitats, which are 
in increasing order over the periphery of the disposal site, are prone to effect of solid waste. During rainy seasons and flood, habitation is affected as the waste is open and scattered.

The municipal boards may draw up a quarterly program of conducting awareness campaign in various wards of the town utilizing the ward committees, local NGOs and resident welfare association. Simple literature may be developed for bringing in the awareness, which may be publicized through media using cable network, and group meetings in different areas through NGOs. The sanitation supervisors may also create awareness during their field visits. As soon as the awareness campaign picks up, the Municipal Boards may direct households, shops and establishments not to mix recyclable waste with domestic food / bio-degradable waste and instead store recyclable / non bio degradable wastes in a separate bin or bag at the source of waste generation. There is no system of primary collection of MSW in any towns. As there is no proper storage bins or centres, the waste is thrown on the streets, drains and on the open spaces. The waste is collected from the streets. There is no provision to collect the waste from small roads and lanes. It is also observed that wastes are scattered here and there on the streets and markets and it is very common to find large heaps of garbage in unorganized manner on the streets and market area which are creating flies, bad smells, mud and finally may create serious environmental and health problems as these waste contain various toxic substances. Street sweeping is not carried out regularly except in some main roads of the towns.

\section{Discussion}

Population growth and particularly the development of megacities is making SWM in India a major problem [15]. Solid waste is now becoming a burning issue for any administration especially in growing city or towns of developing countries, which is a difficult job because of growing population, rapid urbanisation lack of technical development and public awareness. All the major towns of upper Assam are growing very fast and as because of high population and development the towns are facing problem in case of municipal waste management problem. There is an immediate need of improvement in case of technological development and proper manpower management for solid waste management process because population is increasing rapidly resulting in increased waste generation and now at present the towns are producing around total 128 MT of waste as Tezpur Town produces 28 MT of waste, Jorhat Town produces 35 MT of waste and Dibrugarh Town produces $75 \mathrm{MT}$ of waste respectively. All the three Municipalities are facing problem for disposal of waste as the open dumping ground is affecting the people around the site so there should immediate measures for proper scientific disposal of waste either by adopting a



Figure 8: Photo river water is easily visible from dumping site of DMB. composting or recycling project. Municipal Boards have to take some advanced technical measures to handle the waste management further. There is a good scope of Biogas production from wastes of these boards because in average almost $90 \%$ waste is bio-degradable which is very suitable for such projects as done during implementation of Swachh Bharat Mission in Ambikapur, Chhattisgarh for the first time in India. Segregation of wastes is also a very important issue for the towns and need to take care during the collection time as it is observed there is no such measure adopted so far by any towns of upper Assam in this regard and facing problem at time of collection as well as disposal process also. Thus, more public awareness needs to be spread among the citizens. During the field survey it was found that citizens are willing to pay for better waste management for these towns but no such planning is there so far.

In the current comparative study, it has been noticed that, all the towns have problems in term of municipal waste management but among them Dibrugarh town is more critical due to open air dumping system since 25 years on the banks of the river Brahmaputra dike area known as Maizan. It is unsuitable and unscientific area for dumping process and is dangerous both for human health and riparian ecosystem as the site is zero metres away from the River Brahmaputra and the dumped wastes directly mix with river water very easily through water runoff process. Jorhat Town is also facing serious problem with dumping site which requires serious monitoring and amendments in waste management methods. Comparatively, Tezpur town is better as it possess a recycling unit and has already adopted integrated municipal waste management. It is further recommended that Solid Waste Resource Management (SLRM) system should be introduced in all the three municipalities covered during the scope of the current study. Door to door collection of garbage, segregation of dry and wet waste at source, sorting of different components according to waste resource management, selling of the separate waste categories and ultimately generating revenues for door to door waste collection is to be introduced immediately. Constant awareness programmes in the different municipal wards and engagement of people is required to ensure ownership and sustainability of the process. Zero Dustbin Concept should also be introduced to prevent any open dumping of wastes as done in Ambikapur in Chhattisgarh or Vellore in Tamil Nadu. Positive lessons learnt from these cities are to be implemented across Assam to ensure a scientific as well as sustainable waste management system.

\section{Conclusion}

Solid Waste Management is a humongous issue in India. Overpopulation and fast growth of urban life has increased rural urban divide on one hand and compounded a plethora of urban issues on another. It is a high time that responsible government bodies in close cooperation with general public take concrete steps to mitigate such issues without neglecting it further. The current paper seeks to find a solution on these aspects through a comparative analysis of the complex and intricate urban issues in three upcoming townscapes of Assam which is also regarded as the gateway to North East India and is considered a very important urban centre of good governance and global trade in India.

\section{Acknowledgment}

We extend our deep sense of gratitude to Dr Satya Sundar Bhattacharya, Department of Environmental Science, Tezpur University, Assam for his spontaneous guidance and encouragement for this present study. The authors are also thankful to all the municipal boards for their support during the study. We feel humbled by the help and utmost cooperation extended by local residents and 
Citation: Choudhury M, Dutta J (2017) A Comparative Study of Municipal Solid Waste Management Status for Three Major Towns of Upper AssamIndia. Int J Waste Resour 7: 291. doi: 10.4172/2252-5211.1000291

local organisations of study area. We extend our thanks to members of Voice of Environment organisation for their encouragement and continued assistance.

\section{References}

1. Sahu S, Nair SJ, Sharma PK (2014) Review on solid waste management practice in India: A state of art. International Journal of Innovative Research and Development.

2. Yoshizawa S, Tanaka M, Shekdar AV (2004) Global trends in waste generation. TMS Mineral, Metals and Materials publishers.

3. Central Pollution Control Board (CPCB) (2000) Report on management of municipal solid wastes, Delhi, India.

4. Alen AR, Dilon AM, O'Brien M (1997) Approaches to landfill site selection in Ireland. Engineering Geology and the Environment, pp: 1569-1574.

5. Akolkar AB (2005) Status of solid waste management in India Implementation status of municipal solid wastes, management and handling rules 2000. Central Pollution Control Board, New Delhi.

6. Choudhury M, Swarnalatha R (2015) Municipal dumping site of Dibrugarh Town, Assam is unscientific and unsuitable for waste dumping. CSIR Science Reporter 53: 0036-8512.

7. Dyson B, Chang BN (2005) Forecasting municipal solid waste generation in a fast-growing urban region with system dynamics modelling. Waste Management 25: 669-679.
8. Ramachandran M (2014) India's urban confusion: challenges and strategies Copal publishing group, New Delhi.

9. Gupta S, Krishna M, Prasad RK, Gupta S, Kansal A (1998) Solid waste management in India: Options and opportunities. Resource, Conservation and Recycling 24: 137-154.

10. Shannigrahi AS, Chatterjee N, Olaniya MS (1997) Physico-chemical characteristics of municipal solid wastes in mega city. Indian Journal of Environmental Protection 17: 527-529.

11. Jalan RK, Srivastava VK (1995) Incineration, land pollution control alternative - design considerations and its relevance for India. Indian Journal of Environmental Protection 15: 909-913.

12. Den Boer J, den Boer E, Jager J (2007) LCA-IWM: A decision support tool for sustainability assessment of waste management systems. Waste Management 27: 1032-1045.

13. Inazumi S, Ohtsu H, Shiotani $T$, Katsumi T (2011) Environmental assessment and accounting for the waste disposal stream in Bangkok, Thailand. J Mater Cycles Waste Management 13: 139-149.

14. Sarma A (2014) Landscape degradation of river Island Majuli, Assam (India) due to flood and erosion by River Brahmaputra and its restoration. Journal of Medical and Bioengineering.

15. Kumar S, Smith SR, Fowler G, Velis C, Kumar SJ, et al. (2017) Challenges and opportunities associated with waste management in India. R Soc Open Sci 4: 160764 